\title{
An Analysis of Cohesion and Coherence in Written Text of Line Today about Wedding Kahiyang Ayu and Bobby Nasution
}

Tarina Dashela ${ }^{1}$

Yeni Mustika ${ }^{2}$

${ }^{1}$ University of Bina Sarana Informatika Pontianak; tarina.tdl@bsi.ac.id

${ }^{2}$ University of Bina Sarana Informatika Pontianak; yeni.yem@bsi.ac.id

Received: July 11, 2021 Accepted: July 23, $2021 \quad$ Published: July 29, 2021

\begin{abstract}
This research is about an analysis of cohesion and coherence in the written text of the line today about the wedding of Kahiyang Ayu and Bobby Nasution. It is aimed to analyze the terms of cohesion and coherence in the following text. This is a descriptive analysis using analysis guidance "Cohesion and Coherence" proposed by Scott Thornburry (2005) and using the line today as the media. The researchers found lexical cohesion, grammatical cohesion, and rhetorical cohesion in cohesion analysis. The text also involves the Micro-Level Coherence and Macro-Level Coherence. In conclusion, the result of the analysis showed that the text is cohesive but not coherent enough.
\end{abstract}

Keywords: Analysis; Coherence; Cohesion; Written Text

To cite this article: Dashela, T., \& Mustika, Y. (2021). An analysis of cohesion and coherence in written text of Line Today about wedding Kahiyang Ayu and Bobby Nasution. SALEE: Study of Applied Linguistics and English Education, 2(02), 192-203.

https://doi.org/10.35961/salee.v2i02.282

\section{Introduction}

A text is meaningful in communication. It is the original words and form of a written or printed work. A text will be worth it if it makes sense, the reader can understand the messages. But, it will be unworkable if a text is not understood easily. The text can be classified as a good text if it contains both cohesion and coherence elements. 
Writing a text as a kind of discourse, should have a good construction and need the cohesion and coherence to be unified. Halliday and Hasan (1989:2) explain that "a text or a paragraph which uses cohesion and coherence must be good writing". It can be meant that to build a good writing, the writers have to use cohesion and coherence in their writing text. Halliday and Hasan (1976) stated that cohesion is linguistically explicit and signals underlying semantic relationship between text elements. However, Halliday and Hasan (1976) mentioned that a text is coherent which must satisfy two conditions: first is text must be consistent with the context in which it is created, the other is a text must have cohesion; all parts in a text must be connected by cohesive devices. Moreover, coherence is the process of interaction between the reader and the text which can give all the readers ${ }^{\text {ee }}$ expectation and provide the answers of the readers ${ }^{\text {ee }}$ questions. Therefore, the text is called coherence if a text should be interrelated.

Cohesion and coherence are two of special factors that have to exist during writing processes including the organizing of sentences into paragraphs and how sentences are joined together. Hidayat (2016) stated that cohesion and coherence are intangible glue that holds paragraphs together. This argument is supported by Harmer (2007:29) who mentions that cohesion and coherence are the phenomena that complete each other, and elements in the text must be cohesion and coherence. The readers can understand the connections of ideas across sentences if the writing is cohesive.

A text as a whole unit must be related to each other, because a text is not just a sequence of sentences, but a sequence of units. The existence of cohesion and coherence is very important in a text because it can help the readers easily to understand the information. In line with this Xhepa (2016) stated that if there is no cohesion and coherence in a text, the readers will not understand the meaning. In short, a text is not a container full of meaning which readers simply understand, but how the whole of the text are related to each other.

Related to the cohesion and coherence analysis, the researchers, as analyst, tries to analyze the terms of cohesion and coherence in a written text of line today about wedding of Kahiyang Ayu and Bobby Nasution. The researchers were interested in using "Line Today" as the media since it collects and provides information from various Indonesian online mass media with interesting readings about political, social, economic, technology, to lifestyle and entertainment news from the country and abroad, which is viral conversation and updates regularly. The researchers use analysis guidance "Cohesion and Coherence" taken from book "Beyond the Sentence - Scott Thornburry, 2005."

\subsection{Research Question}

Based on the explanation above it can be concluded that the researcher decided to discuss the cohesion and coherence of report text in Line Today.

\subsection{Theoretical Framework}

\section{I.2.1. Cohesion}

The connection between sentences may play a role in connected discourse. To connect the sentences together, a writer needs cohesion. Cohesion refers to the presence or absence of explicit cues in the text that allow the reader to make connections between the ideas in the text, such as overlapping of the words and concepts between sentences; it indicates that the same ideas are being referred to across sentences. No matter what, connectives such as 
because, therefore, and consequently, inform the reader that there are relationships by the ideas and the nature of the relationships." (Crossley \& McNamara, 2010).

Meanwhile, Poudel (2018:4) sounded that Cohesion is like other semantic relations such as synonym, antonym, polysemy, is the relationship of the meanings of one item with other item/s in the text or discourse. Cohesion is all about the relation of meaning in a text. It defines something as a text because a text is a unit of meaning, not a form. It is the source of the text that has a range of meanings related to what is being spoken and written to its semantic environment. It is meant that cohesion is clarified through ties in which every one of the text refers to a single instance of cohesion and expressed partly through grammar and partly through vocabulary. That is why there is grammatical cohesion and lexical cohesion. Setiawan, F \& Taiman (2021) stated that cohesion is stated if there may be an interrelated interaction between one sentence structure and another sentence in a paragraph. Cohesion refers to the presence or absence of explicit cues in the text that allow the reader to make connections between the ideas in the text, such as overlapping of the words and concepts between sentences it is indicate that the same ideas are being referred to across sentences (Crossley \& McNamara, 2010).

According to Halliday \& Hasan (1976:5) as defined earlier, "cohesion is a set of linguistic devices which connect ideas making explicit the semantic relations underlying them". It means that the tool for relating the ideas in the text explicitly through cohesive elements. Moreover, "cohesion refers to the range of grammatical and lexical possibilities that exist for linking an element of language with what has gone before or what follows in a text. This linking is achieved through relations in meaning that exist within and across the sentences" (Halliday \& Hasan, 1976:10). Therefore, cohesion utilizes cohesive ties to sequence and connect sentences together causing a text to be in one piece, not a group of unrelated sentences. Halliday \& Hasan (1976:6) in the book of Cohesion in English, classify cohesion into grammatical and lexical cohesion. The grammatical cohesion includes reference, substitution, ellipsis, conjunction. Meanwhile, lexical cohesion includes reiteration and collocation. This is because both of them are determined by two different elements. They are grammar and words. In the lexico-grammatical level, the distinction can absolutely be drawn.

Cohesion is all about the relation of meaning in a text. It defines something as a text because a text is a unit of meaning, not a form. It is the source of the text that has a range of meanings related to what is being spoken and written to its semantic environment. It is meant that cohesion is clarified through ties in which every one of the text refers to a single instance of cohesion and expressed partly through grammar and partly through vocabulary. That is why there are grammatical cohesion and lexical cohesion.

\section{I.2.2. Coherence}

Like cohesion, coherence is an element that shows the connection of ideas in the text. The Latin verb "Coherence" means stick together. There are some definitions from another perspective. Coherence means sticking together logically. According to Yule (2008:126) coherence is everything fitting together well, and it is not something that exists in words or structures, but something that exists in people. Another statement came from Katrin Mezel, (2017) stated that coherence is a cognitive phenomenon. Coherence recognition is rather subjective as it involves text-and reader-based on the features and refers to the logical flow of interrelated topics in a text, thus establishing a mental textual world. 
Wang and Guo (2014) said that the key to the concept of coherence is not something that exists in the language, but something that exists in people. It is people who make sense of what they read and listen to. They try to arrive at an interpretation which is in line with their experience of the way the world is. Indeed, people's ability to make sense of what they read is probably only a small part of that general ability they have to make sense of what they perceive or experience in the world.

Oshima and Hogue (2006:21) proposed "coherence achieved when the sentences and ideas are connected and flow together smoothly. Each sentence should move from one sentence to the next one logically and smoothly. There must be no sudden jumps". Setiawan, F \& Taiman (2021) added the coherence is stated if there is a logical relationship of meaning between one sentence and another in the paragraph. This can mean that coherence allows the readers to move easily from one idea to the next, from one sentence to the next, and from one paragraph to the next. Coherence involves connection, the connection between parts of sentences, paragraphs, and even larger units will be clear to the reader. The writer should make the connection available to readers and the text meaningful to the readers.

Coherence refers to the functioning of the text as a unified whole. Moreover, "coherence refers to the relationships of ideas and the ability of those ideas to function together for the purpose of conveying the meaning" (Mclinn,1998:15, as cited in Maghfiroh, 2013:20). In fact, any piece of writing has coherence if it represents its argument in a clear, plausible, convincing and comprehensible order. This piece of writing should have no logical gaps in its line of reasoning and it avoids unnecessary digression.

\section{Method}

In conducting this research, the researchers used descriptive analysis as its goals to describe a phenomenon and its characteristics. According to Loeb, Dynarski, McFarland (2017) descriptive analysis characterizes the world or a phenomenon, identifying patterns in the data to answer questions about who, what, where, when, and to what extent. The data source was from Line Today. So, the researchers just copied the text in order to analyze the cohesion and coherence analysis.

\section{Findings and Discussion}

(1) The wedding procession of President Jokowiees daughter Kahiyang Ayu and her fiancé, Muhammad Bobby Afif Nasution, began on Monday afternoon. (2) The procession, which was done in the Javanese tradition, started with a thanksgiving feast called Wilujengan Kenduri, held at Jokowie s private house on Jl. Kutai Utara, Sumber, Surakarta, at 4 p.m. local time. (3) but The president ${ }^{\text {ee }}$ family members and relatives conducted a Qur an recitation. (4) On Tuesday, Jokowi, as the father of Kahiyang, will carry out of a procession called the installment of blektepe (a plait made from coconut leaves) in front of his house. (5) During the Midodareni (eve of the ceremony) on Tuesday evening, Bobby ${ }^{\text {ee }}$ family will deliver peningset, or wedding gifts, to the bride as a symbol of a man ${ }^{\text {ee }}$ c capability to fulfill his wife ${ }^{\text {ee }} \mathrm{s}$ needs. 


\subsection{Cohesion}

Cohesion refers to the resources within language that provide continuity in a text, over and above that is provided by clause structure and clause complex. The cohesion analysis involves lexical cohesion, grammatical cohesion, and rhetorical cohesion.

\subsubsection{Lexical Cohesion}

Lexical cohesion can be developed by some lexical devices, such as direct repetition, synonym, antonym, hyponym, and meronymy. According to the result analysis, it shows all of elements above exist in the text.

Table 1. Direct Repetition

\begin{tabular}{cccl}
\hline No. & Repeated Words & Frequency & Line \\
\hline 1. & Wedding & $2 \mathrm{x}$ & 1,5 \\
\hline 2. & Procession & $3 \mathrm{x}$ & $1,2,4$ \\
\hline 3. & House & $2 \mathrm{x}$ & 2,4 \\
\hline 4. & President & $2 \mathrm{x}$ & 1,3 \\
\hline 5. & Family & $2 \mathrm{x}$ & 3,5 \\
\hline 6. & Tuesday & $2 \mathrm{x}$ & 4,5 \\
\hline 7. & Jokowi & $3 \mathrm{x}$ & $1,2,4$ \\
\hline 8. & Kahiyang & $2 \mathrm{x}$ & 1,4 \\
\hline 9. & Bobby & $2 \mathrm{x}$ & 1,5 \\
\hline
\end{tabular}

\section{Wedding (2x)}

- (1) The wedding procession of President Jokowi's daughter Kahiyang Ayu and her fiancé, Muhammad Bobby Afif Nasution, began on Monday afternoon.

- (5) During the Midodareni (eve of the ceremony) on Tuesday evening, Bobby's family will deliver peningset, or wedding gifts, to the bride as a symbol of a man's capability to fulfill his wife's needs.

\section{Procession (3x)}

- (1) The wedding procession of President Jokowi's daughter Kahiyang Ayu and her fiancé, Muhammad Bobby Afif Nasution, began on Monday afternoon.

- (2)The procession, which was done in the Javanese tradition, started with a thanksgiving feast called Wilujengan Kenduri, held at Jokowi's private house on Jl. Kutai Utara, Sumber, Surakarta, at 4 p.m. local time.

- (4)On Tuesday, Jokowi, as the father of Kahiyang, will carry out of a procession called the installment of blektepe (a plait made from coconut leaves) in front of his house.

\section{House (2x)}

- (2) The procession, which was done in the Javanese tradition, started with a thanksgiving feast called Wilujengan Kenduri, held at Jokowi's private house on Jl. Kutai Utara, Sumber, Surakarta, at 4 p.m. local time. 
- (4)On Tuesday, Jokowi, as the father of Kahiyang, will carry out of a procession called the installment of blektepe (a plait made from coconut leaves) in front of his house.

\section{President $(2 x)$}

- (1) The wedding procession of President Jokowi's daughter Kahiyang Ayu and her fiancé, Muhammad Bobby Afif Nasution, began on Monday afternoon.

- (3) The president's family members and relatives conducted a Qur'an recitation.

\section{Family (2x)}

- (3) The president's family members and relatives conducted a Qur'an recitation.

- (5) During the Midodareni (eve of the ceremony) on Tuesday evening, Bobby's family will deliver peningset, or wedding gifts, to the bride as a symbol of a man's capability to fulfill his wife's needs.

\section{Tuesday (2x)}

- (4) On Tuesday, Jokowi, as the father of Kahiyang, will carry out of a procession called the installment of blektepe (a plait made from coconut leaves) in front of his house.

- (5) During the Midodareni (eve of the ceremony) on Tuesday evening, Bobby's family will deliver peningset, or wedding gifts, to the bride as a symbol of a man's capability to fulfill his wife's needs.

\section{Jokowi (3x)}

- (1) The wedding procession of President Jokowi's daughter Kahiyang Ayu and her fiancé, Muhammad Bobby Afif Nasution, began on Monday afternoon.

- (2) The procession, which was done in the Javanese tradition, started with a thanksgiving feast called Wilujengan Kenduri, held at Jokowi's private house on Jl. Kutai Utara, Sumber, Surakarta, at 4 p.m. local time.

- (4) On Tuesday, Jokowi, as the father of Kahiyang, will carry out of a procession called the installment of blektepe (a plait made from coconut leaves) in front of his house.

\section{Kahiyang (2x)}

- (1) The wedding procession of President Jokowi's daughter Kahiyang Ayu and her fiancé, Muhammad Bobby Afif Nasution, began on Monday afternoon.

- (4) On Tuesday, Jokowi, as the father of Kahiyang, will carry out of a procession called the installment of blektepe (a plait made from coconut leaves) in front of his house.

\section{Bobby (2x)}

- (1) The wedding procession of President Jokowi's daughter Kahiyang Ayu and her fiancé, Muhammad Bobby Afif Nasution, began on Monday afternoon.

- (5) During the Midodareni (eve of the ceremony) on Tuesday evening, Bobby's family will deliver peningset, or wedding gifts, to the bride as a symbol of a man's capability to fulfill his wife's needs. 
Table 2. Synonym, Antonym, Hyponym, and Meronymy

\begin{tabular}{cccc}
\hline Synonym & Antonym & Hyponym & Meronymy \\
\hline Wedding - Procession & - & - & - \\
\hline Tradition - Ceremony & & & \\
\hline
\end{tabular}

\subsubsection{Grammatical Cohesion}

Grammatical cohesion can be developed by some grammatical devices, such as references, comparatives, and tense. According to the result of the analysis, it shows most of the elements above exist in the text.

Table 3. Elements of Grammatical Cohesion

\begin{tabular}{llll}
\hline No. & \multicolumn{1}{c}{ Types } & Example & Frequency \\
\hline 1. & Reference (Pronoun) & His & $2 \mathrm{x}$ \\
\cline { 3 - 4 } & & Her & $1 \mathrm{x}$ \\
\hline 2. & Explicit linking words & And & $2 \mathrm{x}$ \\
\cline { 3 - 4 } & & But & $1 \mathrm{x}$ \\
\cline { 3 - 4 } & & Or & $1 \mathrm{x}$ \\
\hline 3. & Conjuncts/Linkers & - & - \\
\hline 4. & Tense & Present Tense \\
\hline 5. & Rhetorical Cohesion & Members & \\
& (Parallelism) & Relatives & \\
\hline
\end{tabular}

\section{a. Reference: Pronoun}

(1)The wedding procession of President Jokowi's daughter Kahiyang Ayu and her fiancé, Muhammad Bobby Afif Nasution, began on Monday afternoon. (2) The procession, which was done in the Javanese tradition, started with a thanksgiving feast called Wilujengan Kenduri, held at Jokowi's private house on Jl. Kutai Utara, Sumber, Surakarta, at 4 p.m. local time. (3)But The president's family members and relatives conducted a Qur'an recitation. (4)On Tuesday, Jokowi, as the father of Kahiyang, will carry out of a procession called the installment of blektepe (a plait made from coconut leaves) in front of his house. (5) During the Midodareni (eve of the ceremony) on Tuesday evening, Bobby's family will deliver peningset, or wedding gifts, to the bride as a symbol of a man's capability to fulfill his wife's needs.

\section{$\checkmark$ Anaphoric}

It refers to any reference that points backwards to previously mentioned information in text. This reference is used in some following sentences: 
- (1)The wedding procession of President Jokowi's daughter Kahiyang Ayu and her fiancé, Muhammad Bobby Afif Nasution, began on Monday afternoon.

'her' refers to 'Kahiyang Ayu'.

- (4)On Tuesday, Jokowi, as the father of Kahiyang, will carry out a procession called the installment of blektepe (a plait made from coconut leaves) in front of his house.

'his' refers to 'Jokowi'.

- (5) During the Midodareni (eve of the ceremony) on Tuesday evening, Bobby's family will deliver peningset, or wedding gifts, to the bride as a symbol of a man's capability to fulfill his wife's needs.

\section{$\checkmark$ Article}

$$
\text { 'his' refers to 'Bobby'. }
$$

- Definite:

The wedding procession, the procession, the Javanese tradition, the President's family members, the father of Kahiyang, the installment, the bride.

- Indefinite

\section{b. Explicit linking words}

A procession, a Qur'an recitation, a symbol.

And (2x), But(1x), Or (1x)

\section{c. Conjuncts/Linkers}

There is no conjuncts or linkers in this text.

\section{d. Tense}

This text used present tense.

Halliday \& Hasan (1976:31) explained that "reference is the use of a word to refer to an item in the real word or in a text". This can be meant that reference is used to indicate the signaling items which represent in the text.

\subsubsection{Rhetorical Cohesion (Parallelism)}

The president's family members and relatives conducted a Qur'an recitation. The use of the same noun form $(\mathrm{v} 1+\mathrm{s})$ is to adjust to the context; it also indicates that the text is well connected.

\subsection{Coherence}

A text is called coherence if it contains Micro-Level Coherence and Macro-Level

Coherence. Therefore, those criteria are carried out in analyzing this context.

\subsubsection{Micro-Level Coherence}

This analysis focuses on finding whether readers' certain expectation (how the proposition (i.e., meaning) of a sentence is likely to be developed in the above or over of the sentence) is realized or not. In English, clauses and sentences have a simple two-way division between what the sentence is about (its topic) and what the writer/speaker what's to tell you 
about the topic (the comment), (Thornburry, 2005). Moreover, this analysis deals with logical relationships among the sentences. Therefore, in analyzing the present text, the analyst uses the terms of the topic and the comment.

Table 4. Topic - Comment

\begin{tabular}{|c|c|}
\hline Sentence & Analysis \\
\hline \multicolumn{2}{|l|}{ Paragraph 1} \\
\hline $\begin{array}{l}\text { (1)The wedding procession of President } \\
\text { Jokowi's daughter Kahiyang Ayu and her } \\
\text { fiance, Muhammad Bobby Afif Nasution, } \\
\text { began on Monday afternoon. }\end{array}$ & $\begin{array}{l}\text { The topic (The wedding procession of } \\
\text { President Jokowi's daughter Kahiyang Ayu } \\
\text { and her fiancé, Muhammad Bobby Afif } \\
\text { Nasution); the comment (began on } \\
\text { Monday). }\end{array}$ \\
\hline $\begin{array}{l}\text { (2)The procession, which was done in the } \\
\text { Javanese tradition, started with a } \\
\text { thanksgiving feast called Wilujengan } \\
\text { Kenduri, held at Jokowi's private house on } \\
\text { Jl. Kutai Utara, Sumber, Surakarta, at } 4 \text { p.m. } \\
\text { local time. }\end{array}$ & $\begin{array}{l}\text { The topic (The procession which was done } \\
\text { in the Javanese tradition); the comment } \\
\text { (started with a thanksgiving feast called } \\
\text { Wilujengan Kenduri, held at Jokowi's } \\
\text { private house on Jl. Kutai Utara, Sumber, } \\
\text { Surakarta, at } 4 \text { p.m. local time). }\end{array}$ \\
\hline $\begin{array}{l}\text { (3)But The president's family members and } \\
\text { relatives conducted a Qur'an recitation. }\end{array}$ & $\begin{array}{l}\text { The topic (The president's family members } \\
\text { and relatives); the comment (conducted a } \\
\text { Qur'an recitation) }\end{array}$ \\
\hline
\end{tabular}

\section{Paragraph 2}

(4)On Tuesday, Jokowi, as the father of The topic (On Tuesday, Jokowi, as the Kahiyang, will carry out a procession called father of Kahiyang); the comment (will the installment of blektepe (a plait made carry out of a procession called the from coconut leaves) in front of his house. installment of blektepe (a plait made from coconut leaves) in front of his house).

(5)During the Midodareni (eve of the The topic (During the Midodareni (eve of
ceremony) on Tuesday evening, Bobby's the ceremony) on Tuesday evening,
family will deliver peningset, or wedding Bobby's family); the comment (will
gifts, to the bride as a symbol of a man's deliver peningset, or wedding gifts, to the
capability to fulfill his wife's needs.
fulfill his wife's needs).


Table 5. Logical Relation

\begin{tabular}{|c|c|}
\hline Sentence & Description \\
\hline \multicolumn{2}{|l|}{ Paragraph 1} \\
\hline $\begin{array}{l}\text { (1) The wedding procession of President } \\
\text { Jokowi's daughter Kahiyang Ayu and her } \\
\text { fiance, Muhammad Bobby Afif Nasution, } \\
\text { began on Monday afternoon. }\end{array}$ & $\begin{array}{l}\text { Sentence (1) tells about the topic of the } \\
\text { text. }\end{array}$ \\
\hline $\begin{array}{l}\text { (2)The procession, which was done in the } \\
\text { Javanese tradition, started with a } \\
\text { thanksgiving feast called Wilujengan } \\
\text { Kenduri, held at Jokowi's private house on } \\
\text { Jl. Kutai Utara, Sumber, Surakarta, at } 4 \text { p.m. } \\
\text { local time. }\end{array}$ & $\begin{array}{l}\text { Sentence (2) explains the wedding } \\
\text { procession of Kahiyang Ayu and } \\
\text { Muhammad Bobby Afif Nasution. }\end{array}$ \\
\hline $\begin{array}{l}\text { (3)But The president's family members and } \\
\text { relatives conducted a Qur'an recitation. }\end{array}$ & $\begin{array}{l}\text { Sentence ( } 3 \text { ) continues the explanation in } \\
\text { sentence ( } 2 \text { ) about wedding procession. }\end{array}$ \\
\hline \multicolumn{2}{|l|}{ Paragraph 2} \\
\hline $\begin{array}{l}\text { (4)On Tuesday, Jokowi, as the father of } \\
\text { Kahiyang, will carry out of a procession } \\
\text { called the installment of blektepe (a plait } \\
\text { made from coconut leaves) in front of his } \\
\text { house. }\end{array}$ & $\begin{array}{l}\text { Sentence (4) tells about the beginning } \\
\text { activity on Tuesday and gives the name of } \\
\text { procession. }\end{array}$ \\
\hline $\begin{array}{l}\text { (5)During the Midodareni (eve of the } \\
\text { ceremony) on Tuesday evening, Bobby's } \\
\text { family will deliver peningset, or wedding } \\
\text { gifts, to the bride as a symbol of a man's } \\
\text { capability to fulfill his wife's needs. }\end{array}$ & $\begin{array}{l}\text { Sentence (5) is strengthening the previous } \\
\text { information about Tuesday's activity in } \\
\text { wedding procession. }\end{array}$ \\
\hline
\end{tabular}

\section{2,2 Macro-level Coherence}

According to Thornburry, macro-level texts are considered as coherent texts if they are obviously about something in which they have an identifiable topic or topics (2005:51). 
Table 6. Schema

\begin{tabular}{ll}
\hline \multicolumn{1}{c}{ Genre } & Report Text \\
\hline Communicative Purpose & To present information about something, as it is. \\
\hline Linguistic Features & - Using technical or scientific terms. \\
& - Linking verbs and action verbs are used. \\
& - Using present tense \\
& - Using noun phrase \\
\hline
\end{tabular}

Generic Structure

- General Classification

General statements stating that describe the subject of the report, description, and classification.

\section{- Description}

Tells what the phenomenon under discussion is in terms of parts, qualities, habits or behaviors.

Table 7.Scripts

\begin{tabular}{ll}
\hline Paragraph & \multicolumn{1}{c}{ Analysis } \\
\hline Paragraph 1 & $\begin{array}{l}\text { The first paragraph explains the topic which will be } \\
\text { delivered in the text. The writer gives the general } \\
\text { information and classification briefly about who are the } \\
\text { topic in the text, which are Kahiyang Ayu and Bobby } \\
\text { Nasution. }\end{array}$ \\
\hline Paragraph 2 & $\begin{array}{l}\text { The second paragraph explains the process of wedding } \\
\text { procession, namely in Javanese tradition. }\end{array}$
\end{tabular}

Based on the data analysis, the written text is about Kahiyang Ayu and Muhammad Boby Arif Nasution's wedding. There are 2 paragraphs. First, it tells the general information and classification. Then, the second paragraph explains the process of wedding in Javanese tradition. The writer concludes that the text is not coherent but cohesive enough.

Other researchers can be referenced, and compared to better studies. Hopefully the next researcher can investigate more than this research achieved. They can look for the cohesion and coherence device in the different types of texts.

\section{Conclusion}

The text tells about the wedding procession of Kahiyang Ayu and Muhammad Bobby Arif Nasution. It is the kind of report text which has 2 paragraphs. The first paragraph explains the general information or classification and the second paragraph describes the wedding procession explanation. The writer only gives a very short explanation in the second paragraph. The result of the analysis concludes that the text is cohesive but not coherent 
enough. The explanation about the text is not clear at the end of the second paragraph. It only gives the short explanation and a lack of information. It should have coherence which is the process of interaction between the reader and the text. That's why the text can give all the readers' expectations and provide the answers of the readers' questions. Therefore, the text is called coherence if a text should be interrelated. From the above information, it could be concluded that cohesion and coherence play an important role in developing a good text, so that for those who are interested in writing in order to consider the above components in this text.

\section{References}

Halliday, M. A. K, \& Hasan, R. (1976) Cohesion in English. Longman.

Harmer, J. (2007). The practice of English language teaching. Pearson Longman.

Hidayat. (2016). An analysis of grammatical cohesive device of the short story the little match girl by Hans Christian Andersen. English Education Journal.

Loeb, S., Dynarski, S., McFarland, D., Morris, P., Reardon, S., \& Reber, S. (2017). Descriptive analysis in education: A guide for researchers. (NCEE 2017-4023). Washington, DC: U.S. Department of Education, Institute of Education Sciences, National Center for Education Evaluation and Regional Assistance.

Maghfiroh, S. (2013). Coherence Breaks in Essay Made by the 6th Semester Students of English Department of STAIN Salatiga in the Academic Year of 2012/2013.

Menzel, K., Koltunski, E. L., \& Kunz, K. (2017). New Perspectives on Cohesion and Coherence. Language Science Press.

Oshima, A., \& Hogue, Ann. (2006). Writing Academic English. 4th Edition. White Plains, Pearson/Longman.

Poudel, A.P. 2018. Academic writing: Coherence and Cohesion in Paragraph. Dhankuta, Nepal.

Setiawan, F \& Taiman (2021). Cohesion and coherence in written texts of health medical laboratory students. Indonesian EFL Journal, 7(1), 59-68.

Crossley, S \& McNamara, D. 2010. Coherence, Cohesion, and Expert Evaluations of Writing Proficiency. Proceeding of the Annual Meeting of the Science Society.

Thornbury, S. (2005). Beyond the Sentence. Macmillan.

Wang, Y., \& Guo, M. (2014). A Short Analysis of Discourse Coherence. Journal of Language Teaching and Research, 5(2), pp. 460-465.

Xhepa, O. (2016). The importance of accurate cohesion and coherence in the text.

Yule, G. (2008). The study of language. (3rd ed). Cambridge University Press. 